\title{
EFFICACY OF INTERNAL ILIAC ARTERY LIGATION ON THE MANAGEMENT OF POSTPARTUM HEMORRHAGE AND ITS IMPACT ON THE OVARIAN RESERVE
}

\author{
Yavuz SIMSEK, Ercan YILMAZ, Ebru CELIK, Ilgin TURKCUOGLU Abdullah KARAER, Ugur TURHAN, Onder CELIK
}

Department of Obstetrics and Gynecology, Inonu University Faculty of Medicine, Malatya, Turkey

\begin{abstract}
SUMMARY
Aim: Time of surgical treatment for postpartum hemorrhage, still being the most important cause of maternal mortality in the developing countries, could be lifesaving. In the present report, the results of bilateral internal iliac artery ligation in cases with postpartum hemorrhage were presented, in addition, the impact of the procedure on ovarian reserve were discussed.
\end{abstract}

Design and patients: Patients who gave birth between August 2010 and August 2011 in our center, treated surgically due to a diagnosis of postpartum hemorrhage were retrospectively examined.

Setting: A tertiary referral center

Main outcome measures: The obstetric and demographic characteristics, applied surgical procedures, the need for intensive care unit, the amount of transfusion, length of hospital stay and associated morbidities and mortalities were evaluated. Postpartum concentrations of follicle stimulation hormone (FSH) and estradiol with ovarian volume calculated by ultrasonography to evaluate the impact of procedure on ovarian reserve were also examined anc compared normal controls.

Results: The prevalence of postpartum hemorrhage requiring a surgical treatment was $12.5 \%$ during the period of study. Thirteen of those underwent the ligation of bilateral internal iliac artery. The mean age of 32 (24 - 44), mean gravida 3,2 (1 - 5), mean parity 2 (0 - 4), mean birth week 38 (35 - 41) and mean birth weight were $3373 \mathrm{~g}(2500$ - 4200). The effectiveness of bilateral internal iliac artery ligation was $84,7 \%$. FSH and estradiol concentrations and the mean volume of the ovaries were similar between the study (n:10) and control (n:56) groups ( $P=0.650, P=0.245$ and $P=0.281$, respectively).

Conclusion: The ligation of bilateral iliac artery, a fertility preserving method, possess high efficacy for the management of postpartum hemorrhage. The ovarian reserves of patients were not adversely affected by the surgical procedure, as well.

Key words: hemorrhage, postpartum, surgical treatment, uterine atony

Journal of Turkish Society of Obstetrics and Gynecology, (J Turk Soc Obstet Gynecol), 2012; Vol: 9, Issue: 3, Pages: 153- 8

\section{POSTPARTUM KANAMA TEDAVISINDE İNTERNAL İLIAK ARTER LİGASYONUNUN ETKİNLİĞi VE OVER REZERVINE ETKISI}

\section{ÖZET}

Amaç: Gelişmekte olan ülkelerde en önemli maternal mortalite nedeni olan postpartum kanamalarda zamanında uygulanan cerrahi tedavi hayat kurtarıcı olmaktadır. Bu yazlda postpartum atoni tanisı ile bilateral internal iliak arter ligasyonu (BİİLL) yapllan olgularda tedavinin etkinliğ $i$ ve işlemin over rezervine etkisi incelendi.

Planlama ve hastalar: 01 Ağustos 2010 - 01 Ağustos 2011 tarihleri arasında kliniğimizde postpartum atoni tanısl ile BİIAL yapılan hastaların bilgileri retrospektif olarak incelendi.

Address for Correspondence: Dr. Yavuz Şimşek. İnönü Üniversitesi Tıp Fakültesi, Kadın Hastalıkları ve Doğum Anabilim Dalı, Malatya, Turkey Phone: $+90(532) 7119911$

e-mail: dryavuzsimsek@gmail.com

Received: 01 November 2011, revised: 11 January 2012, accepted: 20 March 2012, online publication: 22 March 2012 
Ortam: 3. Basamak bir üniversite kliniği

Değerlendirme parametreleri: Hastaların obstetrik ve demografik özellikleri, uygulanan cerrahi yöntemler, yoğun bakım ihtiyacı, transfüzyon miktarl, hastanede kalış süresi ve eşlik eden morbiditeler araştırıldi. Ek olarak BİIAL yapılan hastalar ve sezaryenle komplikasyonsuz doğum yapan kontrol hastalarının postpartum folikül stimüle edici hormon (FSH) ve estradiol düzeyi ile ultrasonografik over volümleri ölçülerek, işlemin over rezervine etkisi incelendi. Sonuç: Çalışma periyodunda cerrahi tedavi gerektiren postpartum kanama sıklığ $\% 12,5$ saptandı. Bunlardan 13 hastaya BİİL işlemi uygulandı (\%5,3). Hastaların ortalama yaşı 32 (24-44); gravidası 3 (1-5); paritesi 2 (0-4) ortalama doğum haftası 38 (35-41); ortalama doğum kilosu 3373 gr (2500-4200) idi. BİİAL'nin etkinliği \%84,7 saptandı. BİIAL yapılan 10 hastanın over rezervi 56 kontrol hastasıyla karşılaştırıldığında FSH, estradiol düzeyleri ve ortalama over hacmi iki grup arasinda benzer bulundu (Sirasiyla P: 0.650; P:0.245; P: 0.281).

Yorum: Maternal mortalitenin en önemli nedenlerinden olan postpartum kanama olgularının yönetiminde fertilite koruyucu bir yöntem olarak BİİL, yüksek etkinliğe sahiptir. İşlem yapılan hastalarda erken postpartum dönemde over rezervi olumsuz etkilenmiyor görünmektedir.

Anahtar kelimeler: cerrahi tedavi, kanama, postpartum, uterin atoni

Türk Jinekoloji ve Obstetrik Derneği Dergisi, (J Turk Soc Obstet Gynecol), 2011; Cilt: 9, Sayl: 3, Sayfa: 153-8

\section{INTRODUCTION}

Classically, after termination of the third stage of labour, bleeding more than $500 \mathrm{ml}$ is defined as abnormal postpartum bleeding (PPH) ${ }^{(1)}$. Generally, abnormal postpartum bleedings not intervened in due time are responsible for $25 \%$ of maternal mortalities which rise to $60 \%$ in developing countries ${ }^{(2)}$. Another important issue is an increase in chronic morbidities such as kidney failure, respiratory tract problems and severe anemia ${ }^{(3)}$. It was detected that the risk of sudden death within a year among near-death cases of PPH who survived had increased relative to the normal population ${ }^{(4)}$. PPHrelated mortality and morbidities can be prevented with adequate and timely surgical care.

Various surgical techniques have been described in PPH patients refractory to massage and uterotonic therapy. Uterine compression sutures, bilateral uterine artery or internal iliac artery (hypogastric artery) ligation (BIIAL) and as a last resort subtotal or total hysterectomy can be performed(1). In order to save the life of the mother, prompt applicability and effectiveness are critically important issues for the method to be used.

Among them, BIIAL procedure is a surgical approach which decreases pelvic and uterine perfusion at a rate of $75-80 \%$, and also preserves fertility ${ }^{(5)}$. On the other hand, BIIAL procedure is not used prevalently in the obstetrical practice for the following disadvantages. Indeed, various technical details should be meticulously observed, such as retroperitoneum should be entered during ligation, ureters passing immediately over common iliac artery should be visualized and dissected away before the start of ligation, and ligation should be done after clearly visualization of the external iliac artery. In addition, procedure-related important complications as inadvertent suturing of external iliac artery, potential injury to adjacent vascular structures, and a need for a certain amount of surgical experience ${ }^{(6)}$.

In this article, we have presented efficacy of BIIAL procedure and our related clinical experience in a center in which cases with PPH are frequently seen. On the other hand, to investigate the impact of the procedure on ovarian functions, ovarian reserves of patients who had undergone BIIAL with those of the control group who gave birth to healthy babies were compared

\section{MATERIALS AND METHODS}

Our study was planned as a retrospective controlled clinical study performed in accordance with the principles related to experiments in human beings as established in the Declaration of Helsinki after approval obtained from the Ethics Committee. Among patients who delivered babies in our clinics between August 1 2010 and August 1 2011, electronical records of the patients who had undergone BIIAL procedure with the indication of PPH were examined. Obstetrical and demographic characteristics of the patients including age, parity, gravidity, gestational week, and mean birth weight of the babies, pre-, and postoperative blood values, duration of the operation, related complications, 
amount of transfused blood, need for ICU stay, duration of hospitalization, morbidity-mortality information were recorded.

\section{Surgical technique}

An identical surgical approach was used in all cases for BIIAL procedure. With sharp dissection, pelvic peritoneum was opened for approximately $3 \mathrm{~cm}$ from posterior aspect of the round ligament of the uterus. With blunt dissection, the layers of the broad ligament were bisected to enter into retroperitoneal space. Bifurcation of the common iliac artery at the lateral wall of pelvis was revealed. Ureteral coursing anterior to the common iliac artery was denuded down to the level of internal iliac artery and retracted away from the operation field. Capsular formation surrounding internal iliac vessels was opened with sharp dissection to free both artery and vein. A right-angle clamp was passed from outside-in under internal iliac artery $3 \mathrm{~cm}$ distal to the iliac artery bifurcation. Internal iliac artery was ligated $3 \mathrm{~cm}$ distal to the bifurcation with two $3-$ 0 silk sutures placed $1 \mathrm{~cm}$ apart. Pelvic peritoneum was repaired with $2 / 0$ Vicryl sutures. The same procedure was repeated at the contralateral side.

\section{Evaluation of the ovarian reserve}

The impact of BIIAL on ovarian functions was compared with the healthy control group. Ovarian reserve was prospectively evaluated in the BIIAL group. While in the control group, following appropriate patient selection from medical files, the patients were informed, and their ovarian reserves were evaluated. As a control group, age, and gestational week matched patients who had uncomplicated caesarean deliveries comparable with the BIIAL group as indicated in medical files were selected and called for control visits so as to evaluate ovarian reserve. For the control group, the patients with the following exclusion criteria were not included in the study: presence of additional medical or surgical disease, patients aged $>40$ or $<18$ years, smokers, individuals with a history of infertility or usage of assisted reproductive techniques, those who had complications such as diabetes, placenta praevia and placental detachment, antenatal diabetes, ovarian or tubal surgery concomitant with cesarean section, and development of postnatal complications, those who became pregnant during the evaluation process of ovarian reserve, and amenorrheic state within postpartum 12 weeks.
Seventy-one patients complying with these criteria were determined. Among them 7 patients were discarded from the study because they could not menstruate within postpartum 12 weeks. Six patients did not attend the control visit for ovarian reserve evaluation. Two patients denied participation in the study. Finally, control group consisted of 56 patients.

For the evaluation of ovarian reserve in both groups, during early follicular phase of the puerperal period (2. or 3. day of the menstrual cycle) serum follicle stimulating hormone (FSH) and estradiol levels were measured, and also ultrasonographic ovarian measurement parameters were used.

\section{Statistical Analyses}

Data were analyzed using the Statistical Package for Social Sciences (SPSS) software (version 15.0 for Windows). All differences associated with a chance probability of .05 or less were considered statistically significant. Continuous variables are presented as mean \pm SD. Continuous variables were tested for normal distribution with the Kolmogorov-Smirnov test. Groups were compared with independent-sample $t$ test and Pearson chi square test.

\section{RESULTS}

During the study period of one year 1952 deliveries were realized in our clinics. Two hundred and forty four of these patients (12.5\%) were diagnosed as $\mathrm{PPH}$, and 224 $(91.8 \%)$ of them responded to uterine massage and uterotonic treatment. Twenty patients $(8.2 \%)$ required surgical intervention. BIIAL was performed on 13 (5.3 $\%$ ) surgical candidates. Mean age of the patients (32 yrs; 24-44 years), mean number of pregnancies (3.2; 1-5), and births ( $2 ; 0-4)$, mean gestational age at birth (38 wks; 24-44 wks), mean birth weight (3373 g; 2500-4200 g) were estimated. BIIAL was performed for uterine atony $(\mathrm{n}=11 ; 84.7 \%)$, and intractable bleeding secondary to abnormal placental invasion $(n=2 ; 15.3 \%)$. Types of childbirth delivery, additional operations performed with concomitant arterial, and associated placental pathologies are presented in Table I. BIIAL combined with hysterectomy was performed on 3 patients with indications of placenta increata $(n=1)$, and intractable bleeding despite BIIAL procedure $(n=2)$. In these 2 cases BIIAL was deemed to be inadequate $(15.3 \%)$. 
Table I: Types of childbirth delivery, additional operations performed with concomitant arterial, and associated placental pathologies.

\begin{tabular}{llll}
\hline Parameter & & N & \% \\
\hline Types of childbirth & Vaginal delivery & 2 & 15,4 \\
delivery & Caesarean section & 11 & 84,6 \\
Placental pathologies Absent & 6 & 46,2 \\
& Placenta praevia & 5 & 38,4 \\
& Placenta accreta & 1 & 7,7 \\
Additional operationsAbsent & 1 & 7,7 \\
performed & Placenta inccreta & 9 & 69,2 \\
& Lynch suturation & 1 & 7,7 \\
& Total hysterectomy & 3 & 23,1 \\
\hline
\end{tabular}

Mean blood loss, pre-, and postoperative hemoglobin values, amount of blood transfused, and hospitalization periods of the patients are presented in Table II. In none of the patients, procedural complications were seen during and after BIIAL.

Table II: Mean blood loss, pre-and postoperative hemoglobin values, amount of blood transfused, and hospitalization periods of the patients.

\begin{tabular}{ll}
\hline Parameter & Value \\
\hline Mean blood loss $(\mathrm{ml})$ & $1423(500-4000)$ \\
Preoperative hemoglobin values $(\mathrm{g} / \mathrm{dl})$ & $7,1(4,1-10,2)$ \\
Postoperative hemoglobin values $(\mathrm{g} / \mathrm{dl})$ & $9,1(7,7-12,8)$ \\
Intraoperative blood tansfused (unit) & $3,6(1-6)$ \\
Total blood tnasfused (unit) & $4,7(3-11)$ \\
Hospitalization in intensive care (day) & $2,3(0-6)$ \\
Total hospitalization (day) & $6,8(4-17)$ \\
\hline
\end{tabular}

One $(7.7 \%)$ of 13 patients died. Combined BIIAL -total hysterectomy was performed on a patient who referred to our clinics from a different health care center with clinical presentations of hypovolemic shock and consumption coagulopathy because of atonic bleeding following normal childbirth after establishment of diagnosis of atony. The patient who received a total of 17 units of blood died on the postoperative 1 day in intensive care unit because of multiorgan failure and disseminated intravascular coagulation.

Postpartum ovarian reserves of 9 patients who had undergone only BIIAL procedure, and 56 healthy women (control group) were compared. All study patients were in their lactation periods Measurements in the healthy control, and BIIAL groups were done at $11.2 \pm 4.1$, and $9.9 \pm 3.7$ gestational weeks, respectively $(\mathrm{p}>0.05)$. A significant intergroup difference in postpartum ovarian functions was not detected (Table III) $(\mathrm{p}>0.05)$.
Table III: Comparison of postpartum ovarian reserves of patients who had undergone only BIIAL procedure and healthy women.

\begin{tabular}{llll}
\hline $\begin{array}{l}\text { Ovarian } \\
\text { reserve test }\end{array}$ & $\begin{array}{l}\text { BIIAL group } \\
(\mathbf{N}: 9)\end{array}$ & $\begin{array}{l}\text { Control group } \\
(\mathbf{N}: 56)\end{array}$ & $\begin{array}{l}\text { P } \\
\text { Value }\end{array}$ \\
\hline FSH $(\mathrm{IU} / \mathrm{l})^{\mathrm{a}}$ & $8,0 \pm 2.7(4-12)$ & $7,7 \pm 2,4(1-13.7)$ & 0.681 \\
E2 (pg/ml) ${ }^{\mathrm{b}}$ & $59.1 \pm 33.5(22-125)$ & $95.4 \pm 96.9(23-710)$ & 0.679 \\
Ovarian volume & & \\
$\left(\mathrm{cm}^{3}\right)$ & $11.0 \pm 4.5(7.4-21.1)$ & $13.4 \pm 5.7(4.6-28.3)$ & 0.115 \\
\hline
\end{tabular}

\section{DISCUSSION}

In our study, the efficacy of bilateral internal iliac artery ligation performed with the indication of serious obstetrical bleeding was detected to be 84.7 percent. We didn't encounter any procedure-related major complications which were reported in the literature such as major vessel and ureter injury or inadvertent ligation of the external iliac artery ${ }^{(6)}$.

In their recently conducted study including 58 patients, Unal et al. reported effectiveness of the method as 87.9 percent ${ }^{(7)}$. Similarly, in their review of the results of retrospective studies encompassing 52 patients who had undergone internal artery ligation, Chelli et al indicated a $82.45 \%$ success rate ${ }^{(8)}$. Within the frame of literature findings, and results of our study, we think that BIIAL is a life-saving method with smaller number of side effects in obstetrical bleedings refractory to medical treatment.

Indeed, most of the postpartum bleedings can be brought under control with bimanual massage, or uterotonic treatment with oxytocin, methylergonovine and prostaglandins. Ledee et al. reported an incidence of 0.18 $\%$ for postpartum bleeding refractory to aggressive treatment ${ }^{(9)}$. In our study, the rate of PPH requiring surgical treatment was found to be 8.2 percent. Since our hospital is a university hospital of the region with the highest patient circulation, we conceive that the reason for this higher rate can be associated with our multiparous patient population mostly with impaired hemodynamics, and higher risk of postpartum atony who had delivered in an external health care center $(10,11)$

Following BIIAL uterine arterial pressure drops and uterine blood supply decreases at a rate of 85 percent $(10,11)$. BIIAL aids in the achievement of hemostasis. On the other hand, owing to the presence of collaterals between (1) peripheral and central segments of internal iliac artery, (2) peripheral and aortic branches, (3) uterine 
artery and subcutaneous abdominal, ovarian, and renal arteries, development of uterine and pelvic necrosis after the procedure is prevented(12). Spontaneous birth rate after BIIAL was reported as $51.7 \%$, and a decrease in uteroplacental blood was not asserted during pregnancies of these cases ${ }^{(13,14)}$.

Retroperitoneal coursing of internal iliac arteries, and their close vicinity to the ureter necessitate ligation of these vessels before partial ureteral dissection, and perfect knowledge of retroperitoneal anatomy. Since BIIAL requires more expertise than a routine obstetric surgery, internal iliac artery ligation is not preferred by many obstetricians and gynecologists for the management of postpartum bleeding. On the other hand, in the literature serious intraoperative side effects have been reported such as injury to the internal iliac vein or ureter during ligation of internal iliac artery and related mortality, inadvertent ligation of external iliac artery, postprocedural vesical necrosis, development of perineal and gluteal necrosis $(6,9)$. To avoid these side effects before ligation of the artery, observation of external, and common iliac arteries, retraction of the ureter away from the operation field, and ligation of the artery distal to its posterior branches are recommended. To this end, artery should be ligated at least $3 \mathrm{~cm}$ distal to the bifurcation site. In our study, we did not encounter any serious complications cited in the literature. This phenomenon might be related to higher frequency of surgical interventions for the management of postpartum bleeding in our clinics, and resultant moderate surgical experience on this issue.

Since ovaries are mainly perfused by ovarian artery directly originating from aorta and partially by ovarian branch of the uterine artery, in the literature potential risk of adverse impact of BIIAL on ovarian reserves of the patients have been suggested(15). Still some investigators have claimed that this procedure has no unfavorable effect on ovarian functions, and complete consensus has not been reached on this issue ${ }^{(16,17)}$. In our study, postpartum serum FSH, estradiaol values, and ultrasonographic measurements of ovarian volumes in both BIIAL, and the healthy control groups were comparable. Based on these results it can be said that during early postoperative period, BIIAL procedure do not effect ovarian functions adversely. In the literature healthy pregnancies have been reported following BIIAL procedure, however its efficacy on the ovarian reserve in the long-run is not known. Similarly, in the study by Nizard et al. who evaluated the relation between BIIAL, and fertility in the largest series in the literature so far, the authors had not observed infertility in any of 68 patients who had been treated with BIIAL. They also reported that all patients who wished to become pregnant achieved their goals within postoperative 12 months(13).

Baseline FSH and estradiol measurements are most widely used methods for the evaluation of ovarian reserve. In our study, ovarian volumes were also estimated in conjunction with FSH and estradiol measurements. Due to suppressive effects of breastfeeding on follicular development, for the assessment of ovarian reserve, calculation of the number of antral follicles was not preferred. Lass et al. reported that in cases of infertility, ovarian volume is a valuable marker of the ovarian reserve ${ }^{(18)}$. However, ovarian volume is known to decrease with ovarian aging . During menopause, loss in ovarian volume reaches to its peak level(19). With these information in mind, to test the possibility of decrease in the arterial perfusion of ovaries in patients who had undergone BIALL procedures, ovarian volumes of the cases were measured, but any significant difference was not detected between BIIAL and the control groups. As far as we know, changes in ovarian volumes in patients who had been treated with BIIAL have not been debated in the literature.

Our study has some deficiencies. Priorly, our number of patients who had undergone BIIAL are not adequate to determine efficacy of the method, and its impact on ovarian reserve. Besides, they are reflecting the results of a single center. On the other hand, in our study, the outcomes of the patients who had undergone BIIAL were not compared with the results of the patients who had been treated with other surgical treatment alternatives of PPH. Another important deficiency of our study is that levels of serum anti-mullerian hormone which might reflect ovarian reserve with greater accuracy irrespective of the day of the menstrual cycle were not measured. This is related to our limited laboratory facilities. On the other hand, our results demonstrate health state of the patients during early postpartum period. Another important issue is that since our patients were in their lactation periods, our FSH and estradiol measurements have lower reliability Therefore, in order to better understand the mechanism of impact on ovarian reserve during post-BIIAL period, results of longer follow-up periods excluding lactation periods are needed. 


\section{CONCLUSION}

In conclusion internal iliac artery ligation is an easily applicable, safe and effective method in experienced hands for the management of life threatening obstetrical bleedings such as postpartum atony. Before hysterectomy, in order to control life threatening intractable postpartum bleedings especially in young women with lower parities, it should be tried because it is not costly and does not required complex equipment with superior advantages such as scarcity of complications and preservation, and maintenance of fertility.

\section{REFERENCES}

1. Ferrazzani S, Guariglia L, Draisci G, Sorrentino L, De Stefano V, D'Onofrio G et al. Postpartum hemorrhage. Minerva Ginecol. 2005; 57(2): 111- 29.

2. Geller SE, Adams MG, Miller S. A continuum of care mode for postpartum hemorrhage. Int J Fertil Womens Med. 2007; 52(2-3): 97- 105

3. Leung NY, Lau AC, Chan KK, Yan WW. Clinical characteristics and outcomes of obstetric patients admitted to the Intensive Care Unit: a 10-year retrospective review. Hong Kong Med J. 2010; 16(1): 18- 25 .

4. Sousa MH, Cecatti JG, Hardy EE, Serruya SJ. Severe maternal morbidity (near miss) as a sentinel event of maternal death An attempt to use routine data for surveillance. Reprod Health. 2008 Oct $28 ; 5: 6$.

5. Camuzcuoglu H, Toy H, Vural M, Yildiz F, Aydin H. Internal iliac artery ligation for severe postpartum hemorrhage and severe hemorrhage after postpartum hysterectomy. J Obstet Gynaecol Res. 2010; 36(3): 538- 43.

6. Atala C, Biotti M. Ligation of internal iliac artery as treatment of hemorrhage in obstetrics and gynecology. Rev Chil Obstet Ginecol. 1993; 58(2): 119- 25.

7. Unal O, Kars B, Buyukbayrak EE, Karsidag AY, Turan C. The effectiveness of bilateral hypogastric artery ligation for obstetric hemorrhage in three different underlying conditions and its impact on future fertility. J Matern Fetal Neonatal
Med. 2011; 24(10): 1273- 6 .

8. Chelli D, Boudaya F, Dimassi K, Gharbi B, Najjar I, Sfar E et al. Hypogastric artery ligation for post-partum hemorrhage. J Gynecol Obstet Biol Reprod (Paris). 2010; 39(1): 43- 9.

9. Lédée N, Ville Y, Musset D, Mercier F, Frydman R, Fernandez H. Management in intractable obstetric haemorrhage: an audit study on 61 cases. Eur J Obstet Gynecol Reprod Biol. 2001; 94(2): 189- 96.

10. Fatu C, Francu D, Puisor M, Fatu CI. Changes in the arterial pressure after ligation of the hypogastric artery . Rev Med Chir Soc Med Nat Iasi 1996; 100(1-2): 149- 50.

11. Rajaram P, Raghavan SS, Bupathy A, Balasubramanian SR, Habeebullah S, Umadevi P. Internal iliac artery ligation in obstetrics and gynecology. Ten years experience. Asia Oceania J Obstet Gynaecol 1993; 19(1): 71- 5.

12. Fatu C, Francu D, Puisor M, Fatu CI. The morphophysiological consequences of experimental ligation of the hypogastric arteries. Rev Med Chir Soc Med Nat Lasi 1996; 100(3-4): 177- 9 .

13. Nizard J, Barrinque L, Frydman R, Fernandez H. Fertility and pregnancy outcomes following hypogastric artery ligation for severe post-partum haemorrhage. Hum Reprod. 2003; 18(4): 844- 8 .

14. Api M, Api O, Yayla M. Fertility after B-Lynch suture and hypogastric artery ligation. Fertil Steril. 2005; 84(2): 509.

15. Raba G. Effect of internal iliac artery ligation on ovarian blood supply and ovarian reserve. Climacteric. 2011; 14(1): 54- 7.

16. Yildirim Y, Gultekin E, Kocyigit A, Yilmaz C, Ertopcu K, Arioz DT. Color Doppler analysis of pelvic arteries following bilateral internal iliac artery ligation for severe postpartum hemorrhage. Int J Gynaecol Obstet. 2009; 104(1): 22- 4.

17. Raba G, Baran P. Hemodynamic parameters following bilateral internal iliac arteries ligation as a treatment of intrapartum hemorrhage. Ginekol Pol. 2009; 80(3): 179- 83.

18. Lass A, Skull J, McVeigh E, Margara R, Winston RM. Measurement of ovarian volume by transvaginal sonography before ovulation induction with human menopausal gonadotrophin for in-vitro fertilization can predict poor response. Hum Reprod. 1997 Feb; 12(2): 294- 7

19. Domingues TS, Rocha AM, Serafini PC. Tests for ovarian reserve: reliability and utility. Curr Opin Obstet Gynecol. 2010; 22(4): 271- 6 . 